\title{
SUPPLY CHAIN ANALYSIS FOR INDONESIAN NICKEL
}

\author{
ANALISIS RANTAI PASOKAN NIKEL DI INDONESIA
}

\author{
IJANG SUHERMAN and RIDWAN SALEH \\ $R$ \& D Centre for Mineral and Coal Technology \\ Jalan Jenderal Sudirman 623 Bandung 40211 \\ Ph. (+6222) 6030483, Fax. (+6222) 6003373 \\ e-mail: ljang@tekmira.esdm.go.id
}

\begin{abstract}
It is imperative to increase the value-added of mineral product, especially nickel, as mandated in Law Number 4 of 2009. This law forces government and industry to optimize the added value in this country. The importing countries that perform further processing obtain most benefit from this value added. This creates an opportunity to optimize the value-added products in this country. This research aims to map supply chains along with their product flows and their relation to problem identification, to analyze product development in the supply chain, to analyze the performance of the industrial chain and its impacts on the national economy. Thus, efforts to increase the backward and forward linkages of nickel industry through value-added improvement program, as mandated in the law can be run according to plan. The research approaches were undertaken through direct and indirect surveys. From the results, there is an interrelated success between the value-added improvement policy from the Ministry of Energy and Mineral Resources and the downstreaming policy from the Ministry of Industry. This is indicated by a continuous product flow. By 2020, an estimated 71.7 million tons of nickel ore will be absorbed entirely by smelter of processing and refining in the country. Then the products generated by these smelters will be absorbed by approximately $24 \%$ by the domestic stainless steel industry. The contribution to the national economy can boost Gross Domestic Product by approximately $0.526 \%$
\end{abstract}

Keywords: value-added, supply chain, backward-forward linkages, economic contribution

\begin{abstract}
ABSTRAK
Peningkatan nilai tambah produk tambang, khususnya nikel merupakan keharusan, seperti diamanatkan dalam Undang-Undang Nomor 4 Tahun 2009. Negara pengimpor yang melakukan pemrosesan lebih lanjut mendapatkan manfaat paling banyak. Hal ini merupakan peluang untuk mengoptimalkan produk nilai tambah di dalam negeri. Penelitian ini bertujuan untuk memetakan rantai pasokan beserta aliran produknya dan kaitannya dengan identifikasi permasalahan, menganalisis perkembangan produk dalam rantai pasokan, menganalisis kinerja rantai industri, serta dampaknya terhadap perekonomian nasional. Dengan demikian upaya peningkatan keterkaitan industri hulu dan hilir nikel melalui program peningkatan nilai tambah, sebagaimana yang diamanatkan dalam peraturan tersebut dapat berjalan sebagaimana yang telah ditetapkan. Pendekatan penelitian dilakukan melalui survei langsung dan tidak langsung. Dari hasil penelitian diperoleh keberhasilan yang saling terkait antara kebijakan peningkatan nilai tambah dari Kementerian Energi Dan Sumber Daya Mineral dan kebijakan hilirisasi dari Kementerian Perindustrian. Hal tersebut ditunjukkan dengan adanya aliran produk yang berkesinambungan. Pada tahun 2020, diperkirakan sekitar 71,7 juta ton bijih nikel akan diserap oleh pabrik pengolahan dan pemurnian di dalam negeri. Kemudian dari produk pabrik tersebut sekitar 24\% akan terserap oleh industri stainless steel di dalam negeri. Kontribusi kegiatan ini terhadap perekonomian nasional dapat mendongkrak Produk Domestik Bruto sekitar 0,526\%.
\end{abstract}

Kata kunci: peningkatan nilai tambah, rantai pasokan, keterkaitan hulu dan hilir, kontribusi ekonomi 


\section{INTRODUCTION}

The Law Number 4 of 2009 concerning Mineral and Coal Mining, among others, establishing a policy that prohibits the ore export activity and specifies that ores have to be processed first in Indonesia. It seems that the law tries to raise awareness that Indonesia has mineral resources that must be managed properly and have valueadded. This will open up opportunities for companies and investors to build smelters for processing and refinery of nickel ores into Nickel Pig Iron (NPI), ferronickel, and nickel mattes. In addition to strengthening the upstream industry, the creation of this smelter provides another form of support, especially as raw materials for the intermediate industry. The products of the intermediate industry certainly become raw materials for the downstream/final industry link. This is in line with the view of Djamaluddin, Thamrin and Achmad (2012) that Indonesia has a long chain, not only selling raw minerals but also resulting in depletion of mineral resources. This is important because so far Indonesia is known as a mining product producer supported by abundant resources, but it only exports ores and then obtains these ores return in the form of processed products as raw materials for the intermediate industry, even in the form of end products. Until now, many Indonesian mining industrial chains are not connected. Currently, the contribution of nickel to the national economy is still small, i.e. only around Rp 3.138 trillion or $0.025 \%$ of the national revenue (Badan Pusat Statistik, 2017) and most of the need for raw materials of nickel-based industries is met from imports, which amount to approximately of USD 36.0 million.

Therefore, the policy of increasing the valueadded of mining through processing and refinering that has been implemented since 12 January 2014, followed by the relaxation policy for three years, needs to be analyzed and evaluated in terms of their implementation in each link of the supply chain. Using the approach of the nickel supply chain analysis, it is expected that the nickel supply chain and its product flow can be mapped in order to optimize the forward and backward linkages. The integration of the links of backward and forward nickel chain will increase the contribution of this sector to the national economy.

\section{METHODOLOGY}

The nickel supply chain analysis in this research refers to a series of assessments at each link of the industrial chain, from products in the form of nickel ores to the nickel-based products of the intermediate/ downstream industry. These assessments include product development, selling points, value-added, state revenue, and labor absorption. The objectives of the analysis are consistent with the research objectives, namely to map supply chains along with their product flows and their relation to problem identification, to analyze product development in the value chain, and to analyze the performance of the nickel industrial chain and its impacts on the national economy. Thus, efforts to increase the forward and backward linkages of the nickel industry through programs to value-added improvement, as mandated in the law can be run according to plan. The research approaches were undertaken both through direct or indirect surveys. The direct surveys were conducted in several companies, ranging from a nickel ore mining company (mining business permits, hereinafter referred to as mining permit), companies that processes and refines nickel ore into ferronickel (PT Aneka Tambang Tbk.), nickel mattes (PT Vale Indonesia), nickel pig iron (PT Cahaya Modern Metal Industri), up to smelting company NPI which is about to embark on expansion by establishing a stainless steel plant (PT Indoferro) and PT Weda Bay Nickel that is about to build a smelter. As for the indirect research (non-survey), it was conducted in the office including study literature, processing, and analysis. Data were collected using the observation technique, i.e. through guided interviews, as for the processing model and the analysis technique, the research employed the approaches of descriptive statistics and the value-added analysis model.

To facilitate the presentation of data in descriptive statistics, the Excell Program was used and the value-added analysis used the revenue approach, where the value-added of each economic activity was calculated by adding up all production expenses, namely wages and salaries, business surplus, depreciation and net indirect taxes. For the government sector and businesses that are non-profit-making, the business surplus is not taken into 
account. This business surplus includes interest, land rent, and profit.

\section{LITERATURE REVIEW}

\section{Potential and Opportunity of Nickel Development in Indonesia}

In 2016, Indonesia's nickel resource was estimated at $6,233.65$ million tons with a reserve of $3,155.67$ million tons (Figure 1)
(Pusat Sumber Daya Geologi, 2017). The distribution of Indonesia's nickel potential concentrates in Southeast Sulawesi $(47,6 \%)$, Central Sulawesi $(18,7 \%)$, North Moluccas (28,4\%), and orthers (5,3\%) (Pusat Sumber Daya Geologi, 2015).

Based on the (Bray, 2015); in 2016, Indonesia produced 2.247 million tons of nickel or dominated a $6^{\text {th }}$ rank of the world nickel market (Figure 2).

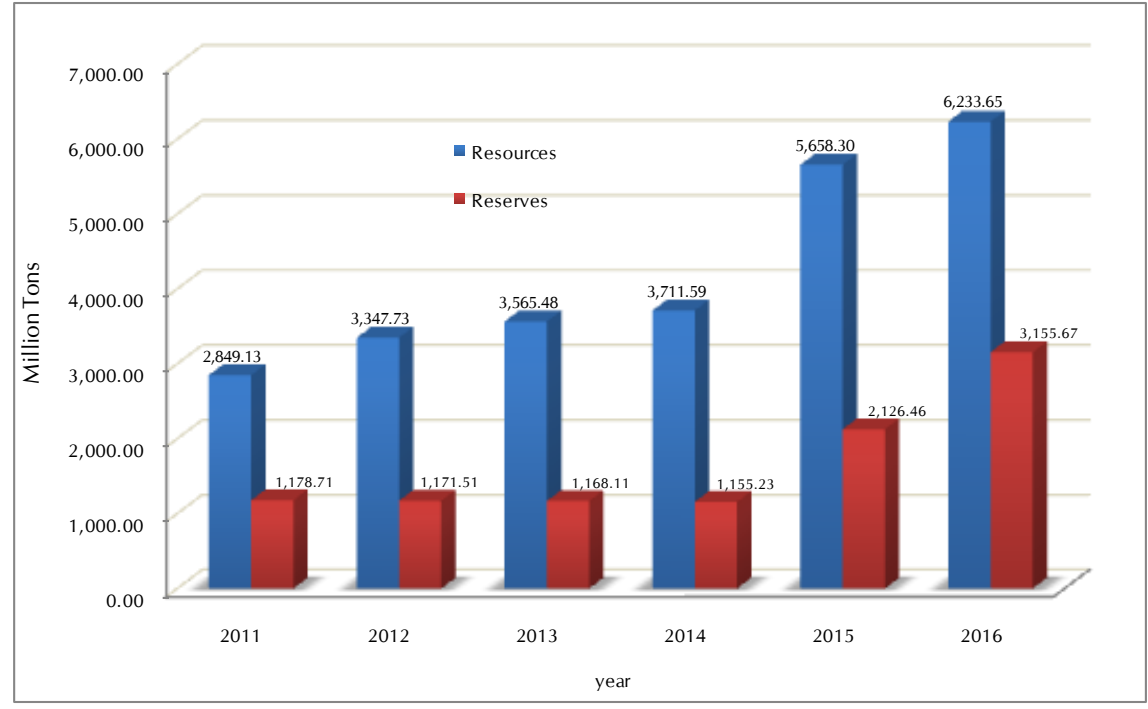

Source: Pusat Sumber Daya Geologi $(2015,2017)$

Figure 1. Indonesia's nickel resources and reserves, 2011-2016 (Pusat Sumber Daya Geologi, 2017)

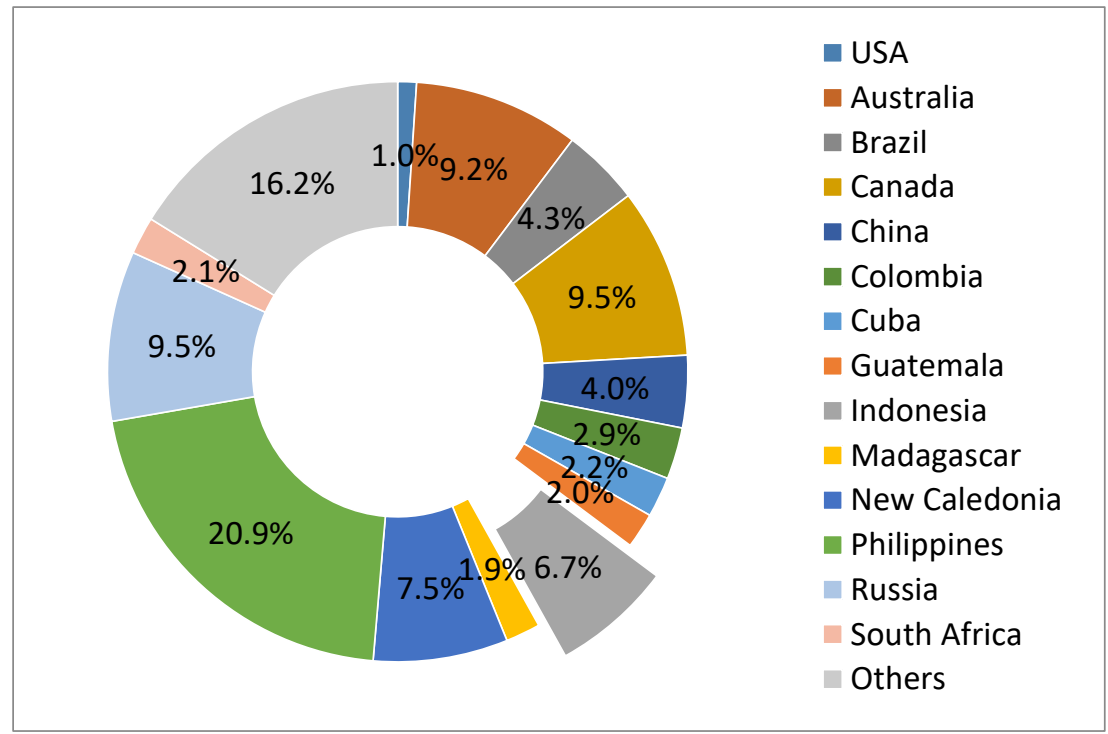

Figure 2. Distribution of nickel production (Bray, 2015) 
The trend of the world nickel production follows a linear regression with the equation of $y=99.5 x+1,300$ with the determination coefficient of $R^{2}=0.842$. In the same period, the nickel consumption follows the trend of linear regression of $y=99.38 x+1,242$ performing determination coefficient of $R^{2}=$ 0.943 (Figure 3). It means that the increases in the nickel production and consumption are 99,500 and 99,380 tons per year respectively. It is predicted that in 2020 such production and consumption will increase to 2.494 million and 2,435 million tons. Based on data from the International Nickel Study Group (INSG) in 2016, the use of nickel is dominated by stainless steel of about $68 \%$ and $16 \%$ to alloy, $9 \%$ plating, and batteries $3 \%$. The rest $(1 \%)$ goes to other purposes (Figure 4).

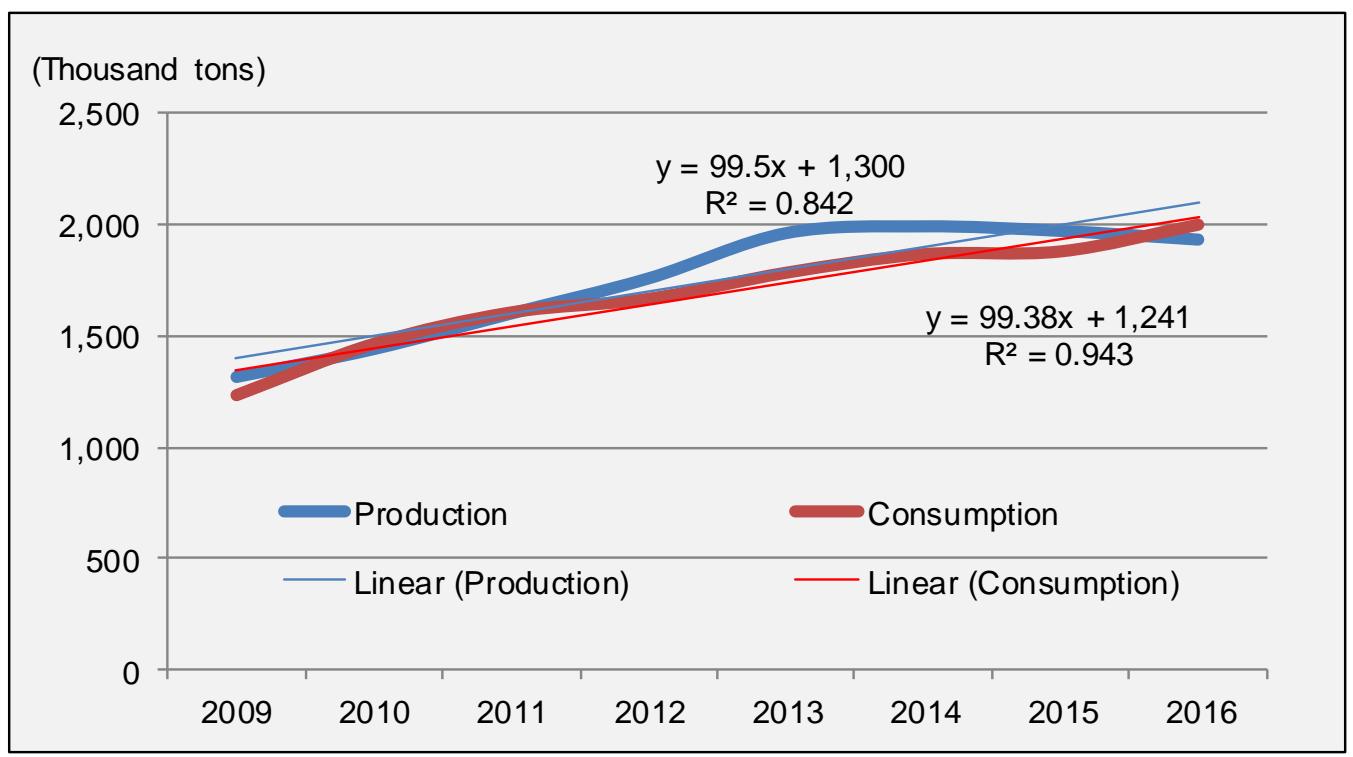

Figure 3. The world's nickel production and consumption 2009-2016 (ISNG, 2016)

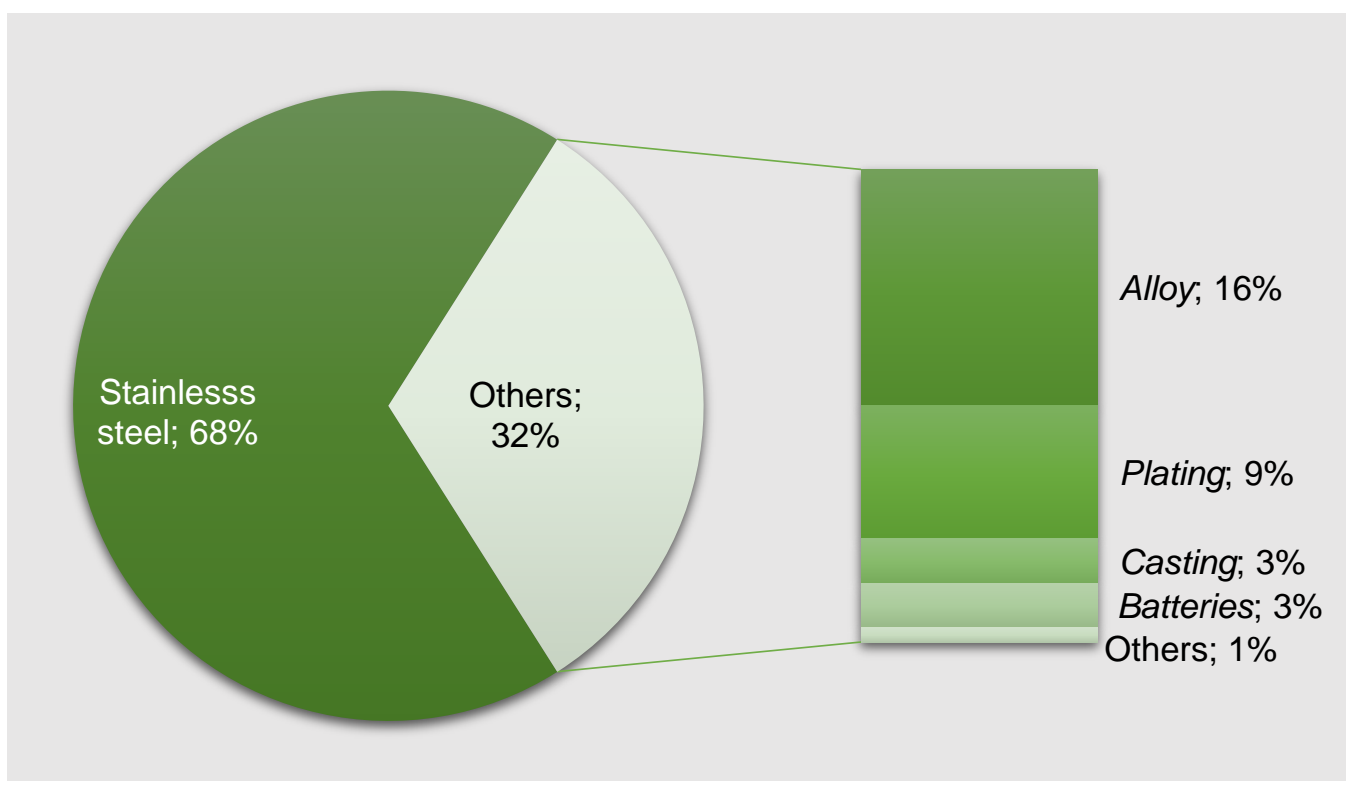

Figure 4. Distribution of nickel utilization in the world (ISNG, 2016) 


\section{RESULTS AND DISCUSSION}

\section{The Nickel Chain Value Concept}

The development of the nickel-based industry still faces problems such as the contribution of nickel to the national economy that remains low, around $0.096 \%$ in 2016, the need for industrial raw materials that is still largely met from imports, and imports of downstream products (finished goods) that flood the domestic market. One of the factors causing the above conditions is the less optimum of forward and backward linkages. Using the supply chain analysis, it is expected that the economic condition of each link can be identified in order to optimize the forward and backward linkages through the value-added improvement policy as mandated in the law and its derivative policies can be implemented as expected.

\section{The Nickel Industry Chain Structure}

In general, the value chain structure of the nickel industry is divided into the following groups: the upstream industry chain, i.e. the mining chain and the mining products are in the forms of nickel ores. These nickel ores are used as raw materials in the processing and refining process. The processing and refining products can be NPI, ferronickel, and nickel mattes, depending on the technology used. Then, these products, i.e. $\mathrm{NPI}$, ferronickel, and nickel mattes, are further processed into the intermediate/ downstream products in the forms of batteries, Ni Alloy, Ni plating, and various stainless steel products. These products will serve as raw materials for their respective downstream industry. Finally, they will be distributed to their end users in the forms of household appliances, ships, construction, agriculture, electronic casing, defense, oil and gas transport, vehicles, and trains (Figure 5).

Based on the figure of the nickel industry chain structure, it can be seen that some of those industries have existed in Indonesia (marked in blue), while the others have not (marked in white). There are many links of the industry chain that still have not been connected, which means that the links of the based backward and forward for nickel industry still yet to be built.

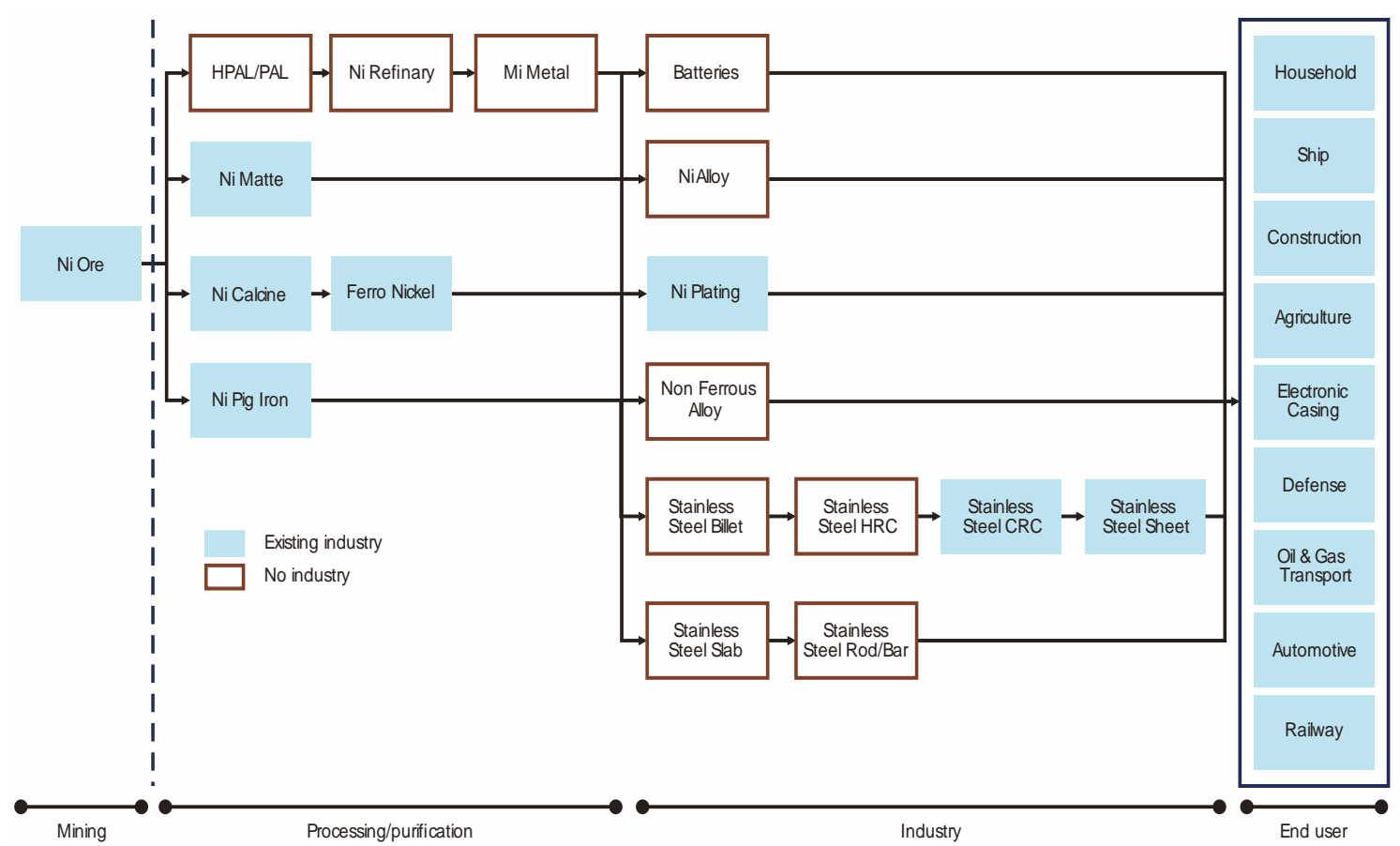

Figure 5. Industrial chain of Indonesian nickel (Directorate General Basis Manufacturing Industry, 2013) 


\section{The Nickel Industry Chain Analysis}

As mentioned above, problems are still found in the Indonesian nickel industry chain structure. This result in less optimal linkages of the nickel supply chain in the country. Prior to the imposition of the value-added improvement (downstreaming) policy, many nickel ores were exported, especially to China. Products of the existing processing and refining industries (PT Vale Indonesia and PT Aneka Tambang) were also exported as a result of the absence of industries that can perform further processing at the mining sites. Meanwhile, the existing industrial business group (intermediate/downstream industries) imported nickel-based raw materials for its production activities. In addition, a fairly high number of finished products were imported in order to meet the needs of the domestic market. Although Indonesia is the world's largest nickel producer, it does not rank among countries producing the largest amount of processed nickel because Indonesian products are sent to the export market in the form of raw materials. The absence of industrialization (intermediate/ downstream industries) nickel-based causes the value-added of this commodity to belong to other countries.

The upstream nickel supply chain is nickel ore mining. Prior to the imposition of the ore export ban policy, companies holding a mining permit sell their products directly to the export market. Even, during the transition period, the number of mining permits increased rapidly and so did the production level. This was observed in the field survey, i.e. the miners ramped up production until the implementation of the export ban. This condition affects that China no longer imports nickel ores from Indonesia to produce stainless steel. After the export ban, nickel ore mining companies did not build smelters or custom plants. Some mining permits build a partnership to supply raw materials to nickel smelters grown domestically.
The Indonesian government provided additional three years of relaxation to build smelters because a lot of companies had difficulties in financial condition. Besides the smelter itself, infrastructure to support production such as power plants, ports, airports, housing facilities (accommodation) for workers, and roads needs to be built as well. These facilities generally remain unavailable in nickel mining areas, which are commonly situated in remote areas in East Indonesia with minimal infrastructure. This industry usually requires the establishment of a large power plant with a capacity of 10$100 \mathrm{MW}$. Therefore, to build a smelter, companies have to spend a lot of money to build these facilities. This is in line with the results of the study conducted by Yunianto (2015) and Prasetiyo (2017) that some parameters of the implementation of the mineral value-added policy still faces many problems which require the government to consistently implement the policy.

The measures taken by the government to stop the export of mineral ores are considered appropriate because they can increase the value of mining products, state revenue, and labor, and as raw materials for intermediate/downstream industry. This policy already begins to produce good results. Based on the data from the Ministry of Energy and Mineral Resources, so far (2017), 15 new smelters have been built, while the construction of the other 14 smelters are still underway. The total investment value reaches approximately USD 9.627 billion (Tables 1, 2, and 3). The existing companies consist of 1 nickel mattes company and 1 ferronickel company (which have been established before the enactment of the Law Number 4 of 2009), 4 new ferronickel companies, 8 NPI companies (2 of them stopped operating), and $1 \mathrm{NiOH}$ company. As for the 14 smelters whose construction are still underway, they consists of 6 ferronickel companies and $8 \mathrm{NPI}$ companies. 

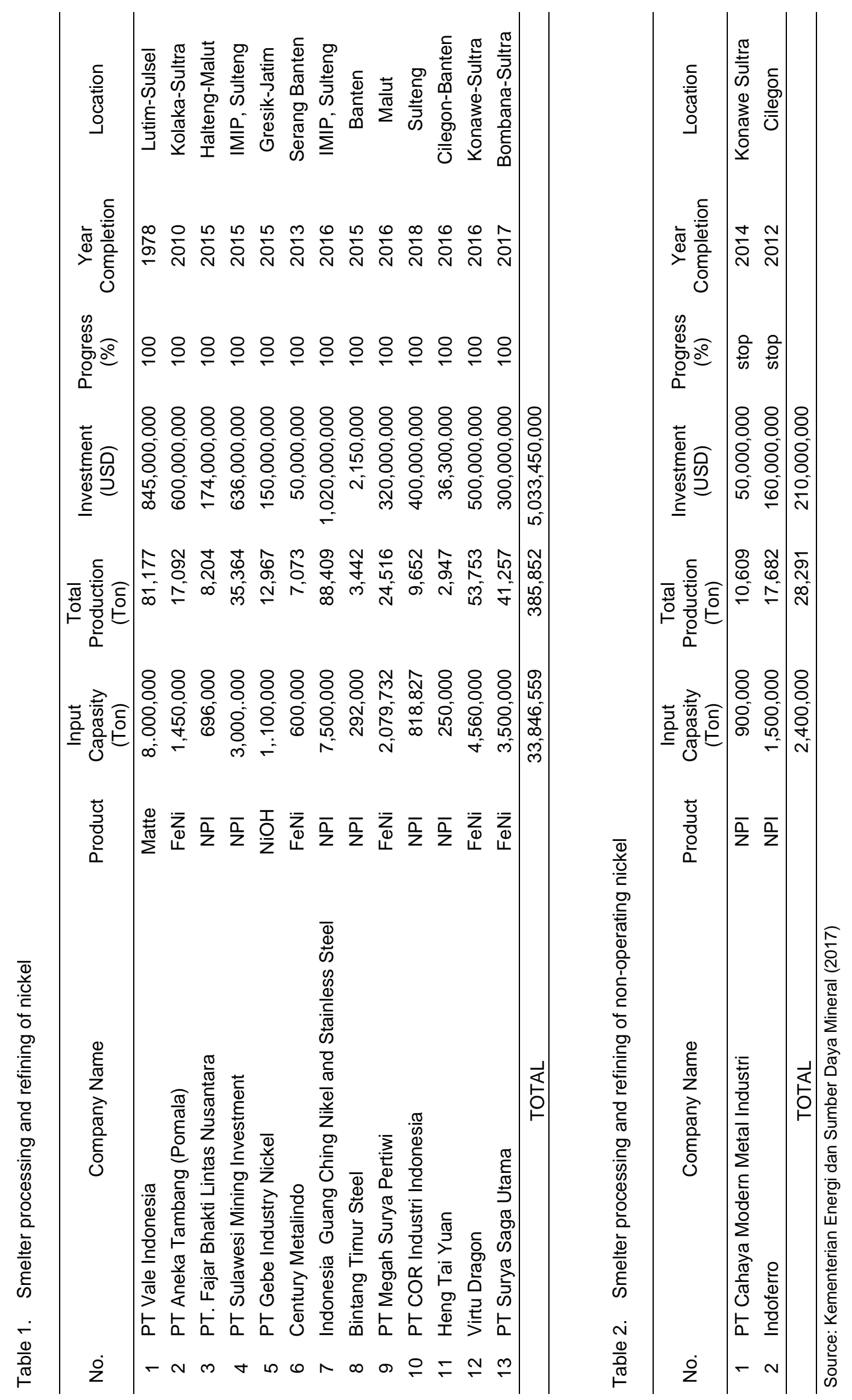


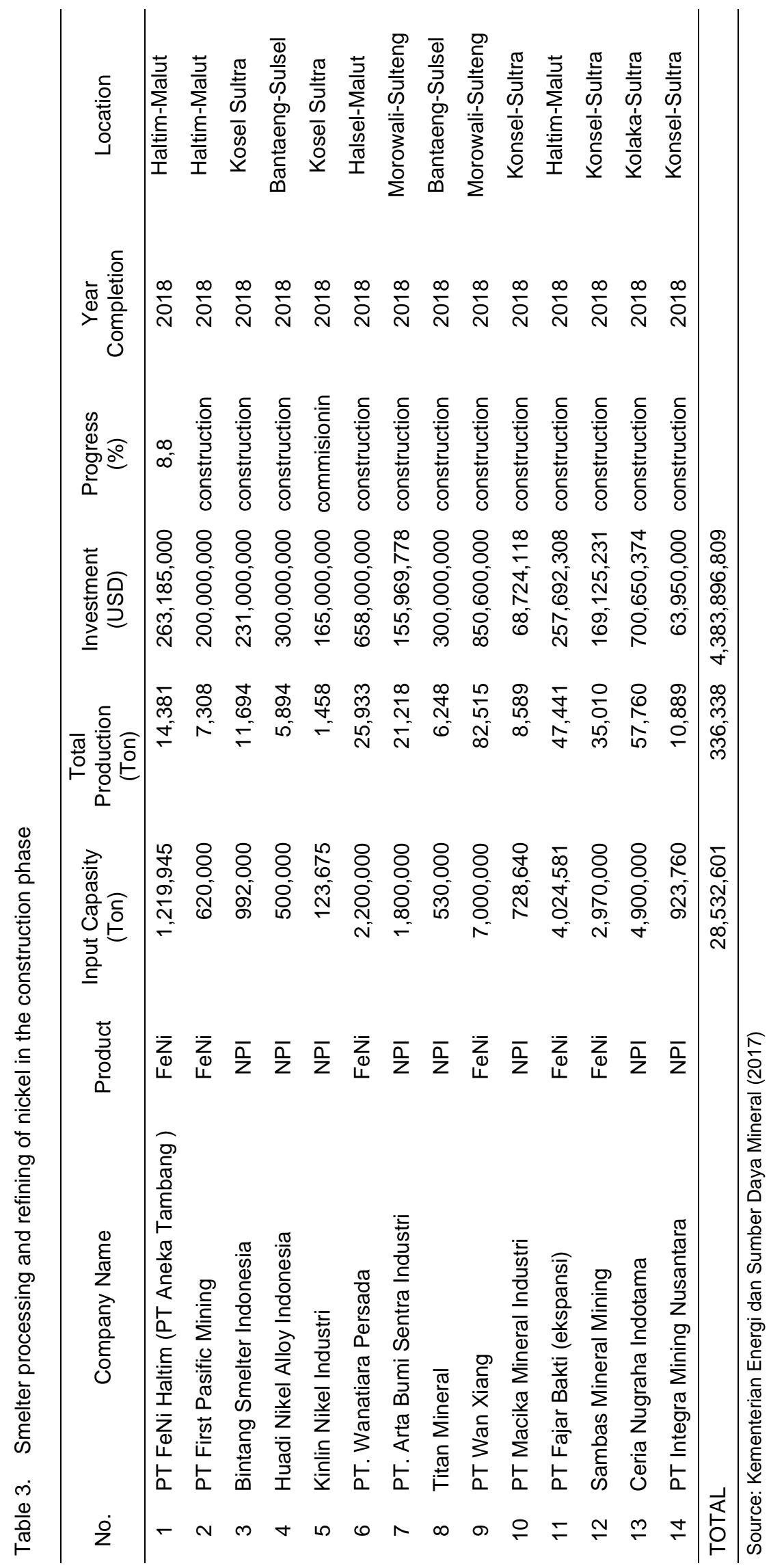


Based on the review by (Ramdan, Prayogo and Nugroho, 2017), the production capacity of Indonesian smelters has increased, from the fourth rank in 2015 became the third rank in 2016. With a rapid rate of development, by 2017, Indonesia is expected to be the first rank in the world in terms of the largest smelter capacity. The considerable number of plans for the construction of those factories at least shows mining investor's interest to make an investment in Indonesia (Haryadi, 2011), and also nickel is a leading commodity (Nursahan, Isnaniawardhani and Sulaksana, 2013). On the other hand, such construction is multi-faceted that have environmental, social, and economic implications (Andana et al., 2015). Related to technology development, Saleh, Rochani and Ardha (2015) conducted a study on the manufacture of ferronickel nugget through a selective semi-solid reduction process using a rotary furnace at a lower temperature to be applicable on a small scale plant.

The nickel-based intermediate industry chain in Indonesia has been developed to the stage of stainless steel production. PT Sulawesi Mining Investment has a production capacity of stainless steel slab of 1 million tons per year. As further measures, PT. Indonesia Guang Ching Nickel and Stainless Steel Industry have performed a commissioning test for a stainless steel plant with a capacity of 1 million tons per year. This is consistent with the strategic objectives of the nickel-based downstreaming policy of the Ministry of Industry, which among other things include reducing import dependence and strengthening the domestic industrial structure so as to strengthen and optimize the multiplier effect arising from the existence of those nickel-based industries. This will boost the gross domestic product and provide employment.

\section{The Analysis of the Development of the Nickel Production Chain}

Before analyzing the performance of the nickel value chain, it is important to analyze the production development of each nickel industry chain, in relation to the enactment of the Law Number 4 of 2009 and the Ministerial Regulation No. 1 of 2014, which has been revised with the Ministerial Regulation No. 8 of 2015.

\section{Production of Nickel Ores}

During the period of transition to the implementation of the ban on nickel ore exports as mandated in the above law that lasted for 5 years (i.e. from 2009 to 2014), the production of nickel ores increased rapidly, by boosted their production and then exported them for further processing to destination countries (Yunianto, 2014). In 2009 , nickel ore production reached 10.437 million tons and in 2013, it reached 65.979 million tons. The nickel ore production from hundreds even thousands of companies holding mining permits was exported mostly to China for processing into stainless steel on a massive scale. After the export ban has come into effect, starting from 2015, there were no longer exports of nickel ores. The year 2015 was a turning point to divert the potential of those nickel ores into raw materials for processing and refines processes in Indonesia. On the other hand, those companies holding the mining permits neither have the technology nor capital to build a smelter, even though the government has provided a solution through the establishment of a "custom plant" through a joint consortium. However, currently, mining activities begin to grow quite fast. It is estimated that by 2020 , the nickel ore supply will reach 71,738 thousand tons (Figure 6). Thus, the production in 2020 is almost equal to the record production in 2013.

\section{Production of Processing/Refining}

In 2014, the Ministry of Energy and Mineral Resources has committed itself to giving priority to improve the value-added of mineral commodities. The Government provides additional 3 years of relaxation time to build the mineral processing and refining industry.

For PT Vale Indonesia, the issuance of Law No 4/2009 did not cause any problems since it has long been undertaking nickel processing and refining. PT Vale Indonesia run one of the world's largest integrated lateritic nickel mining and processing operations, locating near Sorowako on the island of Sulawesi, Indonesia. PT Vale Indonesia's business operations consist of mining and processing of nickel ores into nickel matte, i.e. a product used in the manufacture of refined nickel. Based on the survey, production in 2016 was 
approximated 80,000 tons of nickel mattes, which was lower than that in 2015 that reached 81,177 tons nickel matte, which is the highest. The selling price in 2016 was approximated to USD 624.0 million. In 2017, the target production was approximately 78,000 tons of nickel matte, which was close to actual production in 2016 by 77,581 tons of nickel matte.

For PT Aneka Tambang Tbk., the issuance of the Law Number 4 of 2009 provided an opportunity to embark on an expansion and technological renewal. In 2016, this company in Southeast Sulawesi has just completed its expansion with a capacity of $9,000 \mathrm{~T} \mathrm{Ni}$, thus its total capacity is approximately 28,000 T Ni. This also plans to build a nickel smelter in East Halmahera, North Moluccas.

Since the enactment of the above law, the construction of new nickel smelters was pioneered by PT Cahaya Modern Metal Industri (PT CMMI) which is national private enterprise, in Konawe Regency, Southeast
Sulawesi. The company held a mining business permit for special production operations. The technology used was blast furnace. The technology is suitable for small-scale nickel lateritic ore processing in Indonesia (Astuti et al., 2012). As for disadvantage of the technology, it needs a relatively high quantity of coke that quite expensive in Indonesia (Zulhan et al., 2012). PT CMMI started production in the first half of 2014, produced 1,044 tons of NPI and exported it to China. The company has a 2,000 ha nickel concession area around its plant. There was also PT Macika Mineral Industri which started production. Unfortunately, at the time the survey was conducted in 2016, these companies have stopped operating, because the selling price of LME Nickel was lower than the cost of production. In addition, PT Indoferro in Cilegon, Banten, during the visit, acknowledged that its production was stagnant due to low global prices. However, the company undertook development stage 2 to produce high-grade NPI to expand the construction of a stainless steel plant.

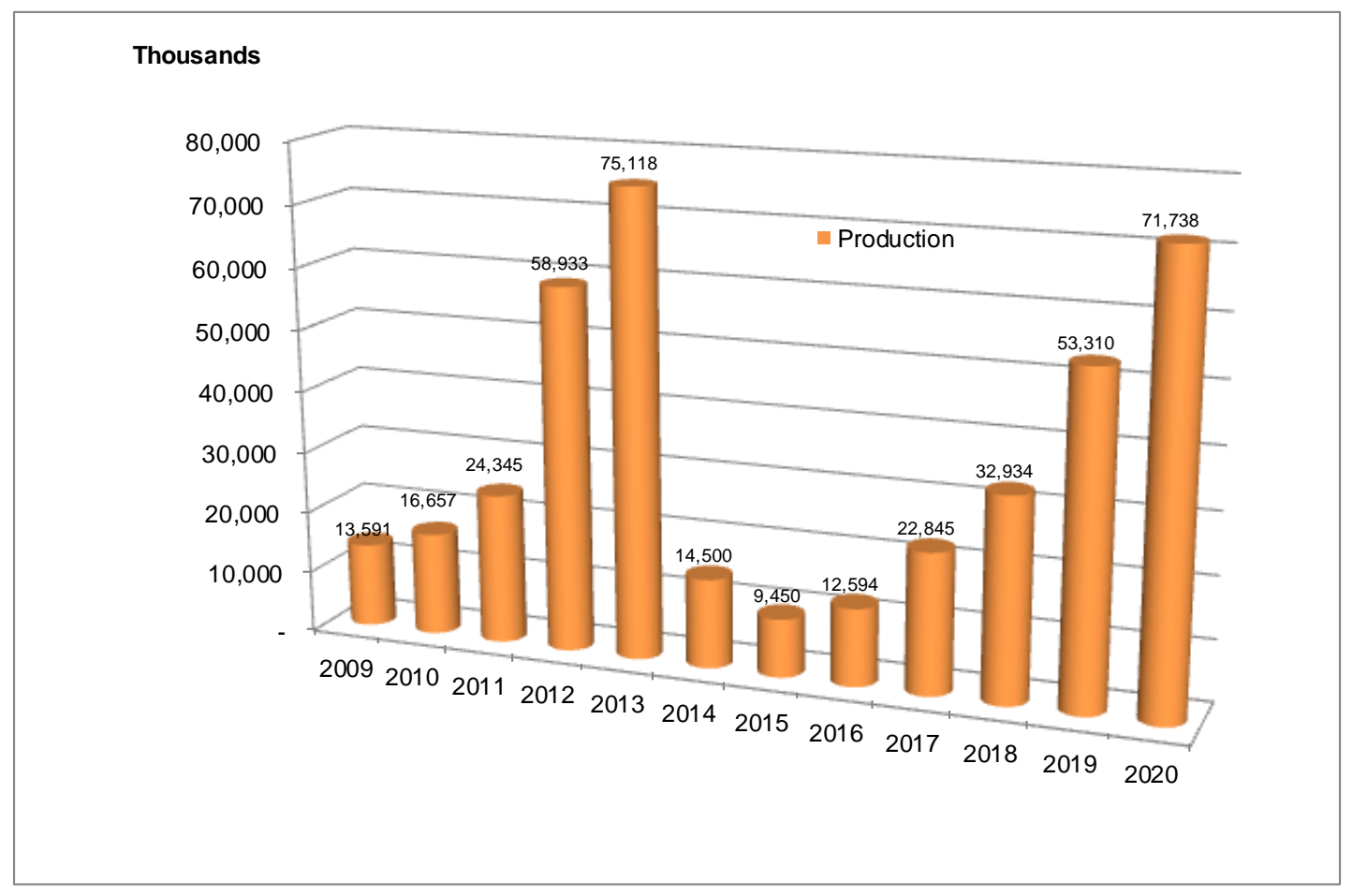

Figure 6. The progress of the amount of Indonesian nickel ore production, 2009-2020 (modified from the Directorate General of Mineral and Coal, 2015) 
Improvements in the development of nickel smelters and other supporting facilities have been found in Morowali Industrial Estate, Central Sulawesi, for example, the operation of the NPI smelter of PT Sulawesi Mining Investment with a capacity of 300,000 tons per year since January 2015. The plant was supported by a steam-fuelled power plant (PLTU) with a capacity of $2 \times 65 \mathrm{MW}$. By 2015 , the company has generated $215,784.11$ tons of NPI per year. The construction of this smelter continued at the second stage with a capacity of 600,000 tons and was supported by the steamfuelled power plant with a capacity of $2 \times$ $150 \mathrm{MW}$. Then, the establishment of the smelter stage 3 is targeted to have a capacity of 300,000 tons and is supported by the steam-fuelled power plant with a capacity of $300 \mathrm{MW}$, which is planned to be completed by the end of 2017. Infrastructure support such as electricity is required in the construction of the smelter (Permana, 2010).

In 2016, an NPI smelter of PT Indonesia Guang Ching Nickel and Stainless Steel Industry were established with a capacity of 600,000 tons per year and were supported by a steam-fuelled power plant with a capacity of $2 \times 150 \mathrm{MW}$. In early 2016, the company's production reached 193,806 tons.

Other smelters that have come into operation are PT Fajar Bakti Lintas Nusantara and PT Megas Surya Pertiwi in North Moluccas, PT Centuri Metalindo and Bintang Timur Steel in Banten, PT Gebe Industry Nickel in East Java, and PT Virtu Dragon and PT Surya Saga Utama in Southeast Sulawesi. These companies have smelters with a production capacity of $7 \%$ NPI of 120,000 tons per year using the blast furnace technology.

The development of nickel production generated from the processing/refining is shown in Figure 7. Based on the figure, it is estimated that up to 2020, the production of nickel matte will be relatively the same as targeted in 2017, which remains higher than $81,177 \mathrm{TNi}$. $\mathrm{NiOH}$ production will reach approximately 12,967 TNi. Ferronickel production will increase from 68,299 $\mathrm{T} \mathrm{Ni}$ in 2017 to 425,336 T Ni by 2020. Similarly, NPI production will increase from 116,706 $\mathrm{T} \mathrm{Ni}$ in 2017 to $341,316 \mathrm{~T}$ Ni by 2020 . Some of the products will enter the markets, especially China and Europe, and some will be processed further into materials to produce stainless steel. Presently, stainless steel industry is being developed in Indonesia.

\section{Production of the Intermediate/ Downstream Industry}

The nickel-based intermediate industry chain in Indonesia is entering the stainless steel production stage. According to the data of PT Indonesia Morowali Industrial Park (IMIP), new projects in Morowali Industrial Estate undertaken in 2016 to 2018 include stainless steel plant of PT Sulawesi Mining Investment with a stainless steel slab production capacity of one million tons per year. Other than that, PT. Indonesia Guang Ching Nickel and Stainless Steel Industry have performed a commissioning test for a stainless steel plant with a capacity of 1 million tons per year.

Therefore, it was estimated that the Morowali Industrial Estate will produce stainless steel by up to two million tons in 2017. By 2018, the production target is three million tons. Production capacity may increase as some nickel-based processing and refining industries (smelters) in that area will expand into stainless steel business. The Ministry of Industry has a target to make Indonesia become one of the largest stainless steel producers in the world. The production capacity of stainless steel in the country is estimated to reach 4 million tons in 2019 (Figure 8).

Thus, the processed and refined products which so far have always been exported will be further processed domestically into materials used to produce stainless steel. If the nickel content in stainless steel is $5 \%$, on average, a total of $200,000 \mathrm{~T} \mathrm{Ni}$ will be required, which is estimated to be equal to $25 \%$ of the production rate of nickel smelters. 
INDONESIAN MINING JOURNAL Vol. 21, No. 1, April $2018: 59$ - 76

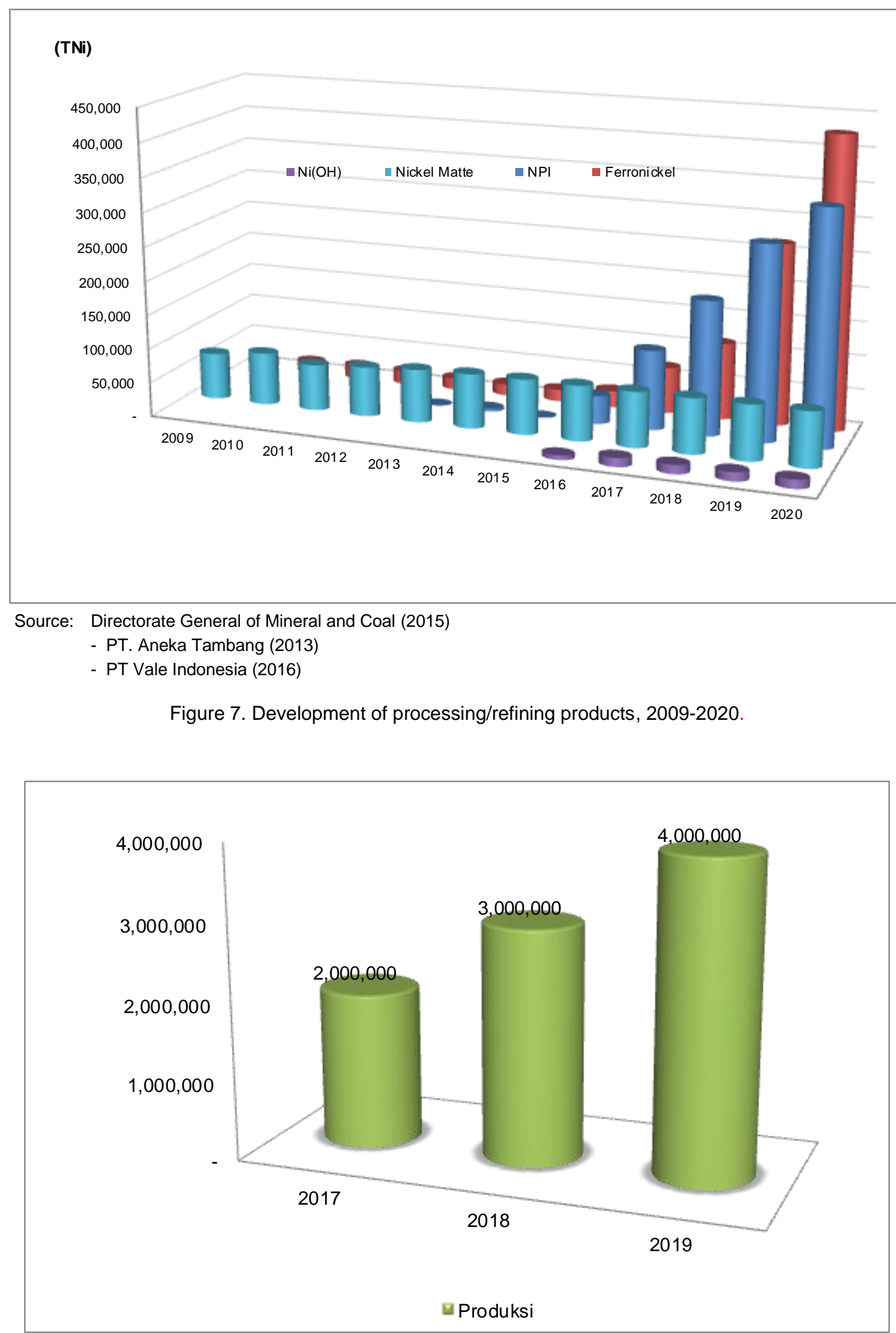

Source: Kementerian Perindustrian (2017)

Figure 8. National stainless steel production target (2017-2019) 


\section{The Analysis of the Performance of the Nickel Industry Chain Using Value-Added}

One method to analyze the performance of nickel supply chain is a value-added calculation. In order to perform comprehensive performance measurement, state revenues and absorption of labor required also need to be calculated. The existence of value-added generated from the nickel industry chain process indicates that the performance of the nickel supply chain is good.

In general, the value-added of mineral processing/refining refers to an increased value as a result of mineral processing and/or refining processes. Linkages to the value chain then can be expanded with the existence of forward linkages (raw materials from the mining process) and backward linkages (which undertake further processing in the intermediate/downstream industry). In the context of processing, value-added can be defined as the differential between the value of the product with the costs of raw materials and other inputs, excluding labor. In other words, the value-added of the process of processing nickel ores into processed products can be obtained by adding up all components which are value-added variables, namely labor costs, taxes and royalties, income from interest, a positive exchange difference, funds allocated to help some areas or society, and the company's profits. The analysis of each link will be performed based on a case study.

\section{The Value-Added of Mining}

For the analysis of the value-added of nickel ore mining, data from the survey conducted at PT Aneka Tambang Tbk. in 2011 and 2013, and PT Macika Mineral Industri in 2016 were used. In this case, there were 65 workers required to generate 1.5 million tons of nickel ore with selling price USD 25.44 per ton or USD 38,160 million totally. Based on the calculation, the value-added obtained is USD 12.395 million or USD 8.26 per ton and delivered state revenues by USD 0.47 per ton (5.7\%) (Table 4). In other words, the potential of nickel reserves if cultivated through mining will provide value-added by USD 8.26 per ton. Thus, when the Law Number 4 of 2009 was enacted, the valueadded amounted to approximately USD 130,879 thousand. In 2016, after going through the transition, it increased to USD 104.064 million. It is estimated that by 2020 there will be a very significant change and the resulting value-added will reach USD 592,767 million. This condition is almost the same as the production level in 2013 before the imposition of the export ban. State revenues are estimated to reach USD 33.823 million, while the direct labor absorption rate is about 20,431 workers. If the value-added is linked to the socioeconomic value and the production trend, the following results are obtained (Table 5).

Table 4. Value-added nickel mining

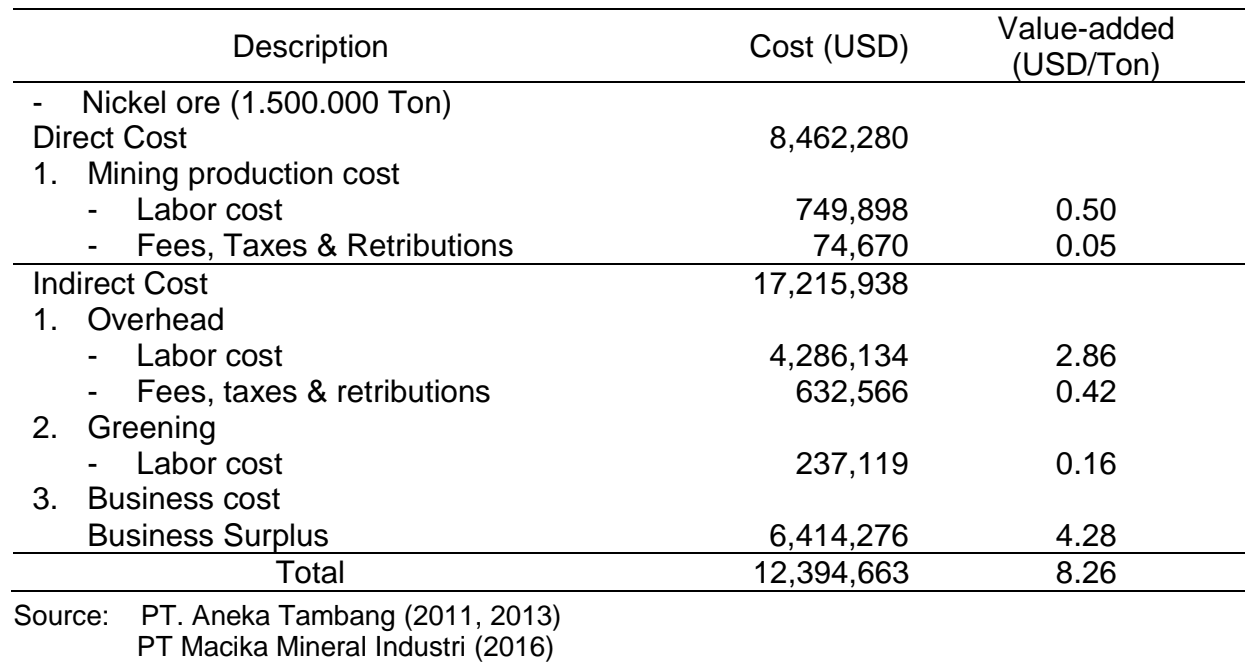


Table 5. Performance of the nickel mining chain

\begin{tabular}{ccccc}
\hline Year & Product & $\begin{array}{c}\text { Value-added } \\
(\text { USD) }\end{array}$ & $\begin{array}{c}\text { State revenue } \\
\text { (USD) }\end{array}$ & $\begin{array}{c}\text { Labor } \\
\text { (people) }\end{array}$ \\
\hline 2016 & Nickel ore & $104,064,222$ & $5,937,875$ & 3,587 \\
2020 & Nickel ore & $592,767,121$ & $33,823,126$ & 20,431 \\
\hline
\end{tabular}

Source : results of processing and analysis

\section{The Value-Added of Processing/Refining}

To calculate the value-added of processing/ refining, the following case study was used, nickel ores as raw materials amounting to $1,062,720$ tons were required to produce 18,250 ton $\mathrm{Ni}$ of ferronickel with total of 1,188 workers. The value-added of the product is approximately USD 98.302 million or USD $5,386.87$ per ton and generated state revenues by USD 516.13 per ton (9.58\%) (Table 6). Thus, the increase in the valueadded resulting from the processing of nickel ores into ferronickel is 4.62 times higher than that resulting from mining activities. Furthermore, the value-added parameters were used to calculate the value-added of other products.

In 2016, the production of ferronickel reached $24,165 \mathrm{TNi}$, which created value-added by USD 130.174 million, generated state revenues by 12.472 million, and labor absorption by 1,595 workers. The valueadded of nickel matte from the production of 78,000 tons is about USD 325.977 million, generating state revenues of USD 24.361 million and labor absorption by 3,086 workers. The value-added of NPI from the production of $41,187 \mathrm{TNi}$ is approximately USD 110.934 million, state revenues by USD 10.629 million and labor absorption by 4,407 workers. The value-added of $\mathrm{NiOH}$ from the production of $6,483 \mathrm{TNi}$ is approximately USD 34.575 million, state revenues by USD 3.313 million and labor absorption by 694 workers. Thus, overall, the value-added generated from the processing and refining value chain is equal to USD 601.660 million, state revenues by USD 50.775 million and labor absorption by 9,781 workers. These figures are expected to increase rapidly up to six times higher by 2020 , where the value-added will increase to USD 3,626.783 million, with state revenues by USD 339.725 million and labor absorption by 69,209 workers (Table 7).

Table 6. The value chain of ferronickel processing

\begin{tabular}{lrr}
\hline \multicolumn{1}{c}{ Description } & Cost (USD) & \multicolumn{1}{c}{$\begin{array}{c}\text { Value added } \\
\text { (USD/Ton) }\end{array}$} \\
\hline $\begin{array}{l}\text { Ferronickel } \\
\text { - Pure Ferronickel Production (18,250 Ton) }\end{array}$ & & \\
Direct Cost & $203,432,003$ & \\
- Raw Material Ore & & \\
- Processing & $4,492,487$ & 246.178 \\
- Labor cost & & \\
- Smelting & $3,355,361$ & 183.866 \\
- Labor cost & & \\
Purification & $4,214,906$ & 230.967 \\
- Labor cost & $48,948,270$ & \\
Indirect cost & $3,015,541$ & 165.245 \\
- Labor cost & $10,214,288$ & 559.719 \\
- Overhead & $1,477,203$ & 80.947 \\
- Labor cost & & \\
: Fees, Taxes \& Retributions & 498,320 & 27.307 \\
- Shipping & 3,145 & 0.172 \\
- Labor cost & $7,938,442$ & 435.008 \\
: Fees, Taxes \& Retributions & $63,095,068$ & $3,457.463$ \\
\hline FeNi Royalty & $98,301,617$ & $5,386.872$ \\
\hline Business Surplus (25\%) & & \\
\hline Total Value-Added Ferronickel & & \\
\hline Source: PT. Aneka Tambang (2011, 2013) & & \\
$\quad$ PT Macika Mineral Industri (2016) & &
\end{tabular}


Table 7. Performance of the processing chains

\begin{tabular}{rlrrr}
\hline Year & \multicolumn{1}{c}{ Product } & \multicolumn{1}{c}{$\begin{array}{c}\text { Value-added } \\
\text { (USD) }\end{array}$} & $\begin{array}{c}\text { State revenue } \\
\text { (USD) }\end{array}$ & $\begin{array}{r}\text { Labor } \\
\text { (people) }\end{array}$ \\
\hline \multirow{3}{*}{2016} & Nickel matte & $325,976,768$ & $24,361,376$ & 3,086 \\
& Ferronickel & $130,174,177$ & $12,472,267$ & 1,595 \\
& NPI & $110,933,799$ & $10,628,805$ & 4,407 \\
& NiOH & $34,575,531$ & $3,312,756$ & 694 \\
\hline \multirow{2}{*}{2020} & $601,660,275$ & $50,775,204$ & 9,781 \\
\hline & Total & $341,087,648$ & $25,490,664$ & 3,229 \\
& Nickel matte & $2,291,231,704$ & $219,527,822$ & 28,072 \\
& Ferronickel & $919,312,325$ & $88,081,285$ & 36,521 \\
& NPI & $69,151,063$ & $6,625,512$ & 1,387 \\
\hline & NiOH & $3,620,782,739$ & $339,725,283$ & 69,209 \\
\hline
\end{tabular}

Source: results of processing and analysis

\section{The Value-Added of the Stainless Steel Industry}

In 2016, there was one the stainless steel industries, which is produced a half of its total capacity by 1 million tons per year. This has an increase the value-added about USD 25.835 million, state revenues of USD 2.475 million, and labor absorption of 1,338 workers. The construction of stainless steel plants until 2019 was aimed to meet the target capacity of 4 million tons. This condition will put Indonesia as one of the countries with the largest stainless steel production in the world. If the capacity in 2020 remains the same, it was estimated that the value-added will reach approximately USD 211.243 million, with the state revenues USD 20.240 million and labor absorption of 5,350 workers (Table 8).

\section{The Impacts of the Nickel Value Chain on the National Economy}

Economic transactions occur at every single stage of the nickel industry chain. These affect the national economy.

Based on data from Statistics Indonesia (Bray, 2015), the National Gross Domestic Product (GDP) in 2016 was equal to Rp9,433,034.4 billion or USD 55.790 billion (by assuming that the average exchange rate is Rp13,900 per dollar), where the Mining and Quarrying sector contributed USD 55.790 billion and the Processing Industry sector contributed USD 145.148 billion. By comparing results of the calculation of valueadded of each nickel industry chain and the national GDP, the magnitude of the contribution can be revealed. In 2016, nickel ore mining products contributed $0.010643 \%$ to the Mining and Quarrying sector or by $0.000875 \%$ to the National GDP. The products of processing and refinement, which consist of nickel mattes, ferronickel, NPI, and $\mathrm{NiOH}$, as well as stainless steel products, contributed $0.44920 \%$ to the Processing Industry sector or $0.096 \%$ to the National GDP.

The contribution was expected to increase remarkably after the realization of the target of the smelter and industrial development in 2020. The contribution of nickel ore mining was estimated to increase to $0.996 \%$ of Mining and Quarrying Sector or $0.070 \%$ of National GDP. While the contribution of processing/ refinement and the stainless steel industry was estimated to increase to $2.355 \%$ of Processing Industry sector or $0.492 \%$ of National GDP. This fact is controversial with Haryadi and Yunianto (2017) statement that said the export-import of Indonesian nickel did not yet provide positive impacts for either national and regional economies.

Table 8. Performance of the stainless steel industry (intermediate industry)

\begin{tabular}{ccccc}
\hline Year & Product & $\begin{array}{c}\text { Value-added } \\
\text { (USD) }\end{array}$ & $\begin{array}{c}\text { State revenue } \\
\text { (USD) }\end{array}$ & $\begin{array}{c}\text { Labor } \\
\text { (people) }\end{array}$ \\
\hline 2016 & Stainless Steel & $25,835,491$ & $2,475,354$ & 1,338 \\
2020 & Stainless Steel & $211,243,133$ & $20,239,658$ & 5,350 \\
\hline
\end{tabular}

Source: results of processing and analysis 


\section{CONCLUSIONS AND RECOMMENDATION}

\section{Conclusions}

The commitment and consistency in implementing the policy to improve the value-added of minerals (the Ministry of Energy and Mineral Resources) and the downstreaming policy (the Ministry of Industry) have produced remarkable results despite lack of support in terms of energy and infrastructure. In addition to PT Aneka Tambang Tbk. and PT Vale Indonesia, which engages in nickel processing activities, currently there are 13 companies that have come into operation and other 14 companies whose construction remains underway. Real investments not less than US \$ 5.243 billion have been made in smelter construction and this amount will increase to USD 9.627 billion. Based on the analysis results, in 2020, the value-added generated from the links of the processing chain will reach USD 3.621 billion in the form of state revenues USD 339.714 million and direct labor absorption of 69,209 workers. With regard to the backward linkage, i.e. the nickel ore mining chain, value-added of USD 592.767 million will be generated in the form of state revenues of USD 33.823 million, and labor absorption of about 20,431 workers. As for the linkages with the intermediate/ downstream industry, i.e. the stainless steel industry, value-added USD 211,243 million will be generated, in the form of state revenues of USD 20.240 million with labor absorption of 5,350 workers. The existence of nickel-based industries will boost the national economy. In 2016, the total contribution of nickelbased industries to the National GDP amounted to $0.108 \%$ and was estimated to able to increase sharply by 2020 to $0.562 \%$.

\section{Recommendation}

Based on the results of the analysis, the following recommendations are offered:

1. The significant growth in the number of processing and refining smelters requires a considerable quantity of nickel ores to be used as raw materials which is almost as high as the record production generated during the era of proliferation of companies holding a mining permit prior to the implementation of the export ban policy. Therefore, a strict supervision is required. Assuming $80 \%$ recovery, Indonesia will have run out of the nickel reserves by 2053 . Therefore, it is imperative to adopt an environmental conservation-based concept. In addition, this needs to be supported by the development of exploratory surveys to support the realization of quality nickel reserves.

2. It is important to give priority to the use of local content for labor, goods, and services in every nickel industry chain, as set out in the Law Number 4 of 2009 Article 106 and the Government Regulation Number 23 Articles 86 to 88 .

\section{ACKNOWLEDGEMENTS}

The author would like to acknowledge Drs. Triswan Suseno and Drs. Jafril who assisted since survey activities in the field through the completion of this manuscript.

\section{REFERENCES}

Andana, R. F., Alimano, M., Hadijah, N. R. and Chaerul, M. (2015) "Cost benefit analysis approach for environmental economic study on nickel smelter processing (case study: PT. Vale Indonesia, South Sulawesi)," in Santoso, B., Ardha, N., Daulay, B., Rochani, S., Umar, D. F., Handayani, S., Damayanti, R., Wahyudi, T., and Ningrum, N. S. (eds.) Proceedings of tekMIRA Colloqium 2015. Bandung: Puslitbang tekMIRA, pp. 133-138.

Astuti, W., Zulhan, Z., Shofi, A., Isnugroho, K., Nurjaman, F. and Prasetyo, E. (2012) "Pembuatan nickel pig iron (NPI) dari bijih nikel laterit Indonesia menggunakan mini blast furnace," in Seminar Insentif Riset SINas. Jakarta: Asdep Relevansi Program Riptek, p. MT66-MT71. Available at: http://biofarmaka.ipb.ac.id/biofarmaka/20 13/PIRS 2012 - file-MT-TeX_11.pdf.

Badan Pusat Statistik (2017) Statistik Indonesia 2017 (Statical yearbook of Indonesia). Badan Pusat Statistik. Available at: https://www.bps.go.id/publication/2017/0 7/26/b598fa587f5112432533a656/statist ik-indonesia-2017.html.

Bray, E. L. (2015) Mineral commodity summaries 2016. Virginia. Available at: https://minerals.usgs.gov/minerals/pubs/ mcs/2016/mcs2016.pdf. 
Directorate General Basis Manufacturing Industry (2013) "Penguatan struktur industri manufaktur menuju akselerasi pembangunan industri." Jakarta, pp. 124.

Directorate General of Mineral and Coal (2015) Indonesia mineral and coal information 2015. Jakarta: Directorate General of Mineral and Coal.

Djamaluddin, H., Thamrin, M. and Achmad, A. (2012) "Potensi dan prospek peningkatan nilai tambah mineral logam di Indonesia (suatu kajian terhadap upaya konservasi mineral)," in Prosiding Hasil Penelitian Fakultas Teknik. Bandung: Institut Teknologi Bandung, pp. 1-13.

Haryadi, H. (2011) "Analisis peranan mineral dan batubara bagi perekonomian nasional," Jurnal Teknologi Mineral dan Batubara, 7(3), pp. 122-136.

Haryadi, H. and Yunianto, B. (2017) "Analysis on terms of trade of Indonesia's nickel," Indonesian Mining Journal, 19(1), pp. 51-64. doi: 10.30556/imj.Vol19.No1.2016.365.

ISNG (2016) Statistics: primary nickel production and primary nickel usage 2009-2014. Lisbon: International Nickel Study Group.

Kementerian Energi dan Sumber Daya Mineral (2017) Investasi dan keberlangsungan operasi fasilitas pemurnian pasca Peraturan Pemerintah Nomor 1 Tahun 2017, www.esdm.go.id. Available at: https://www.esdm.go.id/en/mediacenter/news-archives/investasi-dankeberlangsungan-operasi-fasilitaspemurnian-pasca-peraturan-pemerintahnomor-1-tahun-2017

(Accessed: January 27, 2018).

Kementerian Perindustrian (2017) Pelaku industri ingin formulasi harga gas berbasis produk, www.kemenperin.go.id. Available at: http://kemenperin.go.id/artikel/18200/Pel aku-Industri-Ingin-Formulasi-Harga-GasBerbasis-Produk (Accessed: September 27, 2017).

Nursahan, I., Isnaniawardhani, V. and Sulaksana, N. (2013) "Penentuan kawasan pertambangan berbasis sektor komoditas unggulan sumberdaya nikel Kabupaten Konawe dan Konawe Utara, Provinsi Sulawesi Tenggara," Buletin Sumber Daya Geologi, 8(2), pp. 41-53. Available http://buletinsdg.geologi.esdm.go.id/inde x.php/bsdg/article/view/79.

Permana, D. (2010) "Tantangan dalam peningkatan nilai tambah mineral dan batubara," Mineral dan Energi, 8(4), pp. 4-12. Available at: http://litbang.esdm.go.id/html/publikasi/5 908-majalah-energi-dan-mineral/6985majalah-mineral-dan-energi-desember2010/Majalah Desember 20101 TAN TANGAN DALAM PENINGKATAN NILAI TAMBAH (4-12).pdf.

Prasetiyo, P. (2017) "Tidak sederhana mewujudkan industri pengolahan nikel laterit kadar rendah di Indonesia sehubungan dengan Undang-Undang Minerba 2009," Jurnal Teknologi Mineral dan Batubara, 12(3), pp. 195-207. doi: 10.30556/jtmb.Vol12.No3.2016.139.

PT. Aneka Tambang (2011) Laporan produksi nikel.

PT. Aneka Tambang (2013) Laporan produksi nikel.

PT Macika Mineral Industri (2016) Lembar isian survai data pengolahan bijih nikel. Bandung.

PT Vale Indonesia (2016) Introduction Soroako processing plant.

Pusat Sumber Daya Geologi (2015) Data sumber daya dan cadangan nikel 2015. Bandung.

Pusat Sumber Daya Geologi (2017) Executive summary pemutakhiran data dan neraca sumber daya mineral status 2016.

Ramdan, D. M., Prayogo, O. R. and Nugroho, R. (2017) Jaminan kepastian bahan baku smelter, www.kontan.co.id. Available at: https://industri.kontan.co.id/news/jamina n-kepastian-bahan-baku-smelter (Accessed: January 27, 2017).

Saleh, N., Rochani, S. and Ardha, N. (2015) "Pengaruh penambahan senyawa alkali untuk pembuatan nugget feronikel dalam tungku putar," Jurnal Teknologi Mineral dan Batubara, 11(1), pp. 1-17. Available at: http://jurnal.tekmira.esdm.go.id/index.ph $\mathrm{p} / \mathrm{minerba/article/view/238.}$

Yunianto, B. (2014) "Analisis dampak penerapan kebijakan nilai tambah mineral Indonesia terhadap ekspor dan tenaga kerja," Jurnal Teknologi Mineral dan Batubara, 10(3), pp. 127-141. 
INDONESIAN MINING JOURNAL Vol. 21, No. 1, April $2018: 59$ - 76

Yunianto, B. (2015) "Implementation of value added minerals policy in Indonesia," in Santoso, B., Ardha, I. G. N., Daulay, B., Rochani, S., Umar, D. F., Handayani, S., Damayanti, R., Wahyudi, T., and Ningrum, N. S. (eds.) Proceedings of tekMIRA Colloquium 2015. Bandung: Research and Development Centre for Mineral and Coal Technology, pp. 149159.
Zulhan, Z., Sata, S. Y. A., Astuti, W., Sibarani, D., Nugok, M. D. R. and Bagoes R. A., I. (2012) "Permodelan proses pembuatan nickel pig iron (NPI) dengan blast furnace untuk menentukan kebutuhan kokas, komposisi produk dan terak serta kapasitas pabrik sebagai fungsi dari kandungan nikel di bijih dan volume blast furnace," in The third Indonesian Process Metallurgy Conference (IPM III). Bandung: Institut Teknologi Bandung, pp. 1-10. 